Plaisance (2021)

\title{
ANSERJ
}

Vol. 12, No. S1

Autumn / automne 2021

pp. $65-81$

Canadian Journal of Nonprofit and Social Economy Research

Revue canadienne de recherche sur les OSBL et l'économie sociale

\section{French Nonprofit Organizations Facing COVID-19 and Lockdown: Maintaining a Sociopolitical Role in Spite of the Crisis of Resource Dependency}

\author{
Guillaume Plaisance \\ Research Institute in Management Science, University of Bordeaux
}

\begin{abstract}
COVID-19 became a global health crisis affecting all collective spheres. French nonprofit organizations (NPOs) are trying to participate in the crisis response, but they are suffering from the consequences of the crisis and a structural lack of resources. The aim of this article is to understand how they reacted to the crisis and how they coped with the associated lack. It is based on an extensive survey of French NPOs during the first lockdown. The results show that NPOs considerably reduced their activity while trying to maintain social links. Despite the reorganization of working arrangements during COVID-19, the economic impact of the crisis was very strong.
\end{abstract}

\section{RÉSUMÉ}

La crise sanitaire du Covid-19 devient une crise globale qui touche toutes les sphères collectives. Les associations françaises tentent de participer à la réponse à la crise mais, en dépit de cet engagement, elles subissent de plein fouet les conséquences de la crise et souffrent du manque de ressources qui est déjà structurel chez elles. L'objectif est de comprendre comment elles ont réagi à la crise en composant avec ce manque. L'article s'appuie sur une enquête de grande ampleur auprès des associations durant le premier confinement. Les résultats montrent que les associations ont considérablement réduit leur activité, tout en essayant de maintenir des liens sociaux si possible. L'impact économique est cependant très fort, malgré la réorganisation des modalités de travail.

Keywords / Mots cles: France; Nonprofit organizations; COVID-19 crisis; Resource dependency theory; Stakeholders / Associations; Crise; COVID-19; Théorie de dépendance aux ressources; Parties prenantes

\section{INTRODUCTION}

Whatever the sector, the activity, or the nature of an organization, the COVID-19 health crisis upset its employees, volunteers, and beneficiaries. Nonprofit organizations (NPOs) were both victims of the crisis and key players working to reduce 


\section{Plaisance (2021)}

its impact on society. They had to have two strategies at the same time. They had to do everything they could to ensure their survival, which was under threat (Kim \& Mason, 2020), and they also had to try to maintain their activity as much as possible to preserve a privileged social space for members, volunteers, and beneficiaries. NPOs all share the same objective: to have an impact on society (Kelly \& Lewis, 2009). When society is disrupted by a crisis, NPOs tend to be the first organizations to react, and the positive impact they seek to produce in normal times then becomes particularly crucial.

However, a crisis such as COVID-19 impacts the environment and available resources. Before the crisis, NPOs were already facing resource acquisition problems. The literature has shown that this lack of means not only affects the success of NPOs (Greiling, Harris, \& Stanley, 2016) but also their ability to react to crises and maintain their activity (Loomis, 2020). Beyond organizational success, meeting stakeholder requirements is particularly hindered by a lack of resources. In times of crisis or not, this is one of the main challenges for the nonprofit sector (Mitchell \& Berlan, 2016).

In line with Cathy Barr (2020), the objective of this article is to analyze the resource needs of NPOs and to underline their willingness to maintain their social impact in times of health crisis. The study focuses on the most numerous French NPOs, "associations." They are grassroots volunteer organizations (GVOs), insofar as their governance and day-to-day operations rely primarily on members and volunteers.

This article first focuses on the particularities of French GVOs and the literature on crises. Then it turns to survey questions posed to GVO leaders based on the resource dependency theory. The results are discussed according to the concept of organizational capacity.

\section{FRENCH GVOS, THE CRISIS, AND RESOURCE DEPENDENCY THEORY}

\section{French GVOs as a segment of civil society and the social and solidarity economy}

In France, the Hamon Law of 2014 (Ministère de l'économie, des finances et de la relance, 2014) established a legislative framework defining the social and solidarity economy around three principles. First, these organizations are NPOs: they have "another pursued goal than the sole sharing of profits" (République Française, 2014). Second, their governance is democratic and integrates the stakeholders. Third, the distribution of profits is controlled and dedicated above all to the organization, and the distribution of obligatory reserves is prohibited.

The European vision of a social and solidarity economy is more precise (Stokkink \& Perard, 2015) and specifies that the distribution of benefits is possible if it is equitable. Democratic governance insists on equal voting rights. Finally, two characteristics are crucial: the importance of "social or collective utility" (p. 3) and the plurality of resources, coming from the market as much as from public authorities.

In addition to belonging to this sector, French GVOs have a social role because they sometimes take the place of the state (Evers \& Laville, 2004). Social policy reform (Cabedo, Fuertes-Fuertes, Maset-LLaudes, \& Tirado-Beltrán, 2018) has contributed to this movement. In sports, culture, and the medico-social sector, GVOs are essential, with or without allocated budgets (Dubost \& Zoukoua, 2011). Their local importance is well established, particularly because they are involved in community development (Laville, 2002; Misener, Morrison, Shier, \& Babiak, 2020; Tschirhart \& Gazley, 2014). GVOs are providers of quasi-public goods and services (O'Dwyer \& Unerman, 2008). Their political and civic role is also crucial (Hamidi, 2010) because they have the power to influence, defend, and advocate for their members and some of their stakeholders. They often participate in standards formulation and policy evaluation (Pozil \& Hacker, 2017).

\section{French GVOs before the crisis}

French GVOs represent a large part of the nonprofit private sector. Their total budget is $113 €$ billion, they employ 1.76 


\section{Plaisance (2021)}

million people, and nearly one out of two citizens has been involved with them (Tchernonog \& Prouteau, 2019). The sector continues to grow, and competition exists between GVOs. Their number is indeed rising year by year, while at the same time the number of donors and funders is shrinking (Sargeant, 2001). France currently has about 1.5 million GVOs (Tchernonog \& Prouteau, 2019), but volunteering is not growing as fast as the GVOs sector needs.

The lack of means is one of the major problems of French GVOs. Traditional resource providers have changed their support and now offer more and more in-kind contributions or use "calls for projects" to select the organizations to be financed rather than traditional operating grants (Tchernonog, 2007). Volunteers have also changed their behaviour and are increasingly turning to less formal commitments (Plaisance, 2017). Finally, employees are a very scarce resource, since only 12 percent of French GVOs are employers. Due to this low professionalism of GVOs, the most important resource is time. Thus, management processes are sometimes considered a waste of time.

The literature (e.g., Cabedo et al., 2018; Rey García, Álvarez González, \& Bello Acebrón, 2013) acknowledges that the lack of resources explains the weakness of certain management processes, such as accountability or evaluation. However, these processes are precisely the ones that ensure the engagement of stakeholders who contribute resources. Thus, NPOs in general and GVOs in particular are often blamed for their management shortcomings (Chokkalingam \& Ramachandran, 2015). Governance is poorly developed (e.g., Behn, DeVries, \& Lin, 2010), transparency is often insufficient (e.g., Burger \& Owens, 2010), and the efforts made are rarely sustained over time (Baapogmah, Mayer, Chien, \& Afolabi, 2015).

\section{GVOs in the face of crises}

A crisis can be defined as "a low-probability, high-impact event that threatens the viability of the organization and is characterized by ambiguity of cause, effect, and means of resolution, as well as by a belief that decisions must be made swiftly" (Pearson \& Clair, 1998, p. 3). It usually leads to organizational crises, which

occur fairly often, such as when NPOs are exposed to irregular situations such as reduced budgets, increased competition from nonprofit and for-profit organizations, and reduced institutional support, and this necessitates performance under financial constraints. (Mano, 2010, p. 345)

The COVID-19 crisis is affecting NPOs across borders. It upsets the organization, its management, and its governance (McMullin \& Raggo, 2020) and has particularly negative effects on its financial health (Kim \& Mason, 2020). The effects of a crisis on NPOs are threefold. First, crises affect the NPOs' ability to maintain their day-to-day activities, particularly for their members and/or beneficiaries. Second, crises prevent NPOs from fulfilling their sociopolitical role among communities. Finally, crises destabilize the financial and economic health of NPOs, which is already fragile. In short, the survival of NPOs is in question because their viability is defined on the basis of the three preceding items (Dadić \& Ribarić, 2020; Omura \& Forster, 2014; Weerawardena, McDonald, \& Mort, 2010).

As noted, NPOs were already facing resource management issues before the COVID-19 crisis. An exogenous crisis then complicates the access to these resources. The COVID-19 crisis prevented French GVOs from mobilizing their volunteers when mobility restrictions were in place. The anticipation of an economic and financial crisis, linked to indebtedness and the forced shutdown of the economy, also led GVOs to question the permanence of their partnerships, financial or not. Under these circumstances, the crisis forced GVOs to adapt and break organizational routines (Mano \& Rosenberg, 2014). They had to react and make decisions to stop the vicious circle, especially in terms of resources access.

\section{Resource dependency theory in times of crisis}

Resource dependency theory is concerned with the positioning of an organization in its environment. This environment 


\section{Plaisance (2021)}

provides the necessary resources for the survival of the organization, but they are scarce (Pfeffer \& Salancik, 1978). The organization becomes dependent on this environment, in other words, on the stakeholders who provide the key resources. This theory also notes that the environment is not always favourable to the organization: stakeholders may have bad intentions, interests may diverge, and, of course, global crises may occur.

The strategy of an organization is, therefore, to react to the situation of resource dependency. This dependency is inevitable, but it must be managed and reduced. More generally, the environment is qualified by this theory as uncertain, complex, and unpredictable. Reducing resource dependency makes it possible to reduce the uncertainty and unpredictability of the environment.

In short, resource dependency theory integrates the risk of crises and recognizes that the survival of an organization depends on the resources at its disposal. It is, therefore, applicable to GVOs and the COVID-19 crisis. The aim of this research is to determine the extent to which resource dependency aggravated the consequences of the crisis on French GVOs. In sum, the research questions (RQs) could be phrased as:

RQ1: To what extent has the COVID-19 crisis affected the resources of French GVOs?

$\mathrm{RQ} 2$ : How have the resources available before the crisis protected these organizations?

\section{Hypothesis development}

The concept of organizational capacity can be seen as a relevant analytical filter to answer to these research questions. It is defined as the "ability to fulfill one's mission and meet stakeholders' expectations, which depends on the resources available" (Mourão, Pereira, \& Moreira, 2017, p. 846). The concept and the theory share several characteristics. They note the uncertainty and complexity of the environment and emphasize the scarcity of resources and the need to act according to these particularities. They also underline that the organizational goal is to respond to the demands of the environment, represented in particular by a network of stakeholders that must be satisfied. Organizational capacity guides the organizational strategy, which consists of arbitrating between resources to achieve the mission, according to the resource dependency theory.

Organizational capacity produces outputs and outcomes, in particular toward stakeholders and society in general. Both resource dependency theory and the concept of organizational capacity emphasize the importance of environmental satisfaction. According to Burton Weisbrod (1988), NPOs came to supplement the state when it had reached the limit of its action to compensate for the shortcomings of the market economy. On the specific case of "associations," according to Cyrille Ferraton (2004), who analyzed Alexis de Tocqueville's concept of "association," GVOs allow the poorest to attain a form of ownership through organized and institutional charity. The common good and the "higher interest" for the collective exist thanks to the sacrifices of a few who provide assistance and solidarity to others. In sum, Hypothesis 1 is: despite the resource crisis faced by organizations, the essence of GVOs around public goods and solidity would push them to maintain their sociopolitical role.

Organizational capacity is influenced by the environment, which is more or less favourable, as well as by the provided resources. Resource dependency theory also emphasizes that the organizational environment is paramount to understanding how GVOs work. Thus, Hypothesis 2 is: the sector to which GVOs belong is a determinant of their reaction to the crisis in the short term, regarding their activity and their cash flow.

Organizational capacity allows for a better understanding of the organization's resources, which are mostly intangible (Sobeck \& Agius, 2007). Its structure is made according to the types of resources but is quite variable in the literature 


\section{Plaisance (2021)}

(Hall, 2004; Hall, Andrukow, Barr, Brock, de Wit, \& Embuldeniya, 2003). The three main dimensions of the concept are financial, human, and structural capacities. Michael H. Hall, Alison Andrukow, Cathy Barr, Kathy Brock, Margaret de Wit, and Don Embuldeniya (2003) provide a definition for each of these dimensions: financial capacity is "the ability to develop and deploy financial capital (i.e., the revenues, expenses, assets, and liabilities of the organization)" (p. 5); human resources capacity is "the ability to deploy human capital (i.e., paid staff and volunteers) within the organization, and the competencies, knowledge, attitudes, motivation, and behaviors of these people" (p. 5); and structural capacity is "the ability to deploy the non-financial capital that remains when the people from an organization have gone home" (p. 5). In this framework, the human capital is a determinant of the others. Thus Hypothesis 3 is: financial and human resources capacities help GVOs to cope with the crisis in the short term, regarding their activity and their cash flow.

\section{METHODS}

To answer the research questions, several analyses need to be conducted:

1. An analysis of the activity maintenance, which reflects the evolution of the tangible resources available to the French GVOs (i.e., material, human, or financial resources).

2. An analysis of the persistence of the sociopolitical role of French GVOs, which reflects the evolution of the intangible resources available to these organizations.

3. An analysis of the financial and economic health of French GVOs, which directly addresses the availability of financial resources.

4. If possible (when the variables will not be binary), an analysis of the effects of the crisis on the previous issues through the filter of the environment (represented by the sector) and of the financial and human resources before the crisis.

In France, during the first wave of the COVID-19 epidemic, the authorities instated a very harsh lockdown. This decision led to the closure of most public places and private ones, too. Companies, public services, NPOs, and GVOs had to accept an unprecedented rule: face-to-face work became the exception. Exits from the home were subject to attestations for very restrictive and specific reasons. Only essential goods and services were available.

The survey used for this study was constructed and carried out by the main players in the sector. The first is Le Mouvement associatif, the main federation of GVOs, whose mission oscillates between representation and advocacy. The second is the Réseau National des Maisons des Associations (National Network of Associations Centres), which supports GVOs in their development. The third is Recherches \& Solidarités, a network of experts, professionals, and academics who study GVOs. The survey was conducted in collaboration with a department of the Ministry of National Education and Youth dedicated to GVOs.

Once the questionnaire had been constructed, it was distributed electronically among all the above-mentioned networks with the support of the public authorities. The survey was published on March 20, 2020, just after the announcement of the lockdown.

The present sample includes the 20,419 GVOs leaders' responses, which were received until April 24, 2020. For methodological reasons, this study should be considered as a work on a database. The questions were imposed and the variables are only qualitative. The details of the questions as well as the proposed answers can be found in Table 1. 
Plaisance (2021)

Table 1: Questionnaire sent to NPOs and descriptive statistics of associated variables

\begin{tabular}{|c|c|c|c|c|c|}
\hline Questions and proposed answers & Modality name & $N$ & Mean & Median & $S D$ \\
\hline \multicolumn{6}{|l|}{ Conjuncture and economic impact (contextual data) } \\
\hline $\begin{array}{l}\text { Today, what is the impact of the current coronavirus crisis on the daily and ordinary } \\
\text { activity of your NPO? (1: yes and 0: no) }\end{array}$ & Impact on the activity & 20,333 & 0.8945 & 1 & 0.3073 \\
\hline Have you been forced to cancel or postpone one or more events? (1: yes and 0: no) & Cancelled/delayed events & 20,139 & 0.9274 & 1 & 0.2595 \\
\hline \multicolumn{6}{|l|}{$\begin{array}{l}\text { If the NPO has employees, what solutions have you considered for some or all of them? } \\
\text { (multiple choices - for each answer, } 1 \text { : yes and 0: no) }\end{array}$} \\
\hline Recourse to compensated work stoppage for childcare (14 days) & Work stoppage for childcare & 20,419 & 0.1405 & 0 & 0.3475 \\
\hline Use of short-time working & Partial unemployment & 20,419 & 0.4319 & 0 & 0.4953 \\
\hline Recourse to the FNE-formation (National Employment Fund) & FNE-formation & 20,419 & 0.0046 & 0 & 0.0677 \\
\hline Use of telework & Teleworking & 20,419 & 0.3296 & 0 & 0.4701 \\
\hline Face-to-face work with respect to preventive measures & Face-to-face work & 20,419 & 0.0838 & 0 & 0.2772 \\
\hline \multicolumn{6}{|l|}{$\begin{array}{l}\text { Regardless of the size of your NPO and its sector of activity, what economic impact do } \\
\text { you foresee at about six months? (multiple choices - for each answer, 1: yes and 0: no) }\end{array}$} \\
\hline A significant loss of income from activities & Significant loss of revenue & 20,419 & 0.3753 & 0 & 0.4842 \\
\hline $\begin{array}{l}\text { A total loss of income from activities, taking into account the NPO's mode of } \\
\text { intervention and official instructions }\end{array}$ & Total loss of income & 20,419 & 0.1552 & 0 & 0.3621 \\
\hline A loss of grant(s) related to the cancellation of an activity or event & Loss of subsidies & 20,419 & 0.2909 & 0 & 0.4542 \\
\hline A drop in public financial aid & Decrease in public aid & 20,419 & 0.2544 & 0 & 0.4355 \\
\hline A drop in private financial aid & Decrease in private aid & 20,419 & 0.2144 & 0 & 0.4104 \\
\hline $\begin{array}{l}\text { Expenditures incurred that are no longer required because activities have been } \\
\text { cancelled }\end{array}$ & Unnecessary expenses & 20,419 & 0.1843 & 0 & 0.3878 \\
\hline A cash-flow difficulty linked to a postponement of activities and financing & Difficulty of cash flow & 20,419 & 0.3188 & 0 & 0.4660 \\
\hline It's too early to answer that question & It's too early to say. & 20,419 & 0.3138 & 0 & 0.4640 \\
\hline Have you experienced cash flow difficulties in 2019? (1: yes and 0: no) & Cash difficulties in 2019 & 19,338 & 0.2252 & 0 & 0.4177 \\
\hline
\end{tabular}


Plaisance (2021)

Table 1 (continued)

\begin{tabular}{|c|c|c|c|c|c|}
\hline Questions and proposed answers & Modality name & $N$ & Mean & Median & $S D$ \\
\hline \multicolumn{6}{|l|}{ Social roles (in order to test Hypothesis 1) } \\
\hline \multicolumn{6}{|l|}{$\begin{array}{l}\text { Have you maintained links and relationships with the volunteers in your NPO? (multiple } \\
\text { choices - for each answer, } 1 \text { : yes and 0: no) }\end{array}$} \\
\hline Yes, in a spirit of solidarity (long-distance exchanges, mutual aid, etc.) & Links maintained for solidarity & 20,419 & 0.5987 & 1 & 0.4902 \\
\hline $\begin{array}{l}\text { Yes, by pursuing activities at a distance when they allow it (project development, } \\
\text { preventive measures, communication, operation...) }\end{array}$ & Links maintained for activity & 20,419 & 0.5041 & 1 & 0.5000 \\
\hline Yes, through exchanges of information on the current life of the NPO & Links maintained by info & 20,419 & 0.3568 & 0 & 0.4791 \\
\hline Yes, some of them can continue to operate in the field & Links maintained in the field & 20,419 & 0.0473 & 0 & 0.2122 \\
\hline No, relations with volunteers are suspended due to lockdown measures & No link maintained & 20,419 & 0.1656 & 0 & 0.3718 \\
\hline \multicolumn{6}{|l|}{$\begin{array}{l}\text { Have you mobilized or do you plan to mobilize volunteers from your NPO to maintain } \\
\text { links with your members and/or beneficiaries during this very special period? (multiple } \\
\text { choices - for each answer, 1: yes and 0: no) }\end{array}$} \\
\hline Keep in touch & Keep in touch & 19,618 & 0.7291 & 1 & 0.4444 \\
\hline Relay official messages & Relay official messages & 19,184 & 0.7278 & 1 & 0.4451 \\
\hline Provide some services (shopping, childcare...) & Providing services & 17,762 & 0.1496 & 0 & 0.3567 \\
\hline Guide them through administrative procedures & Guide to administrative procedures & 17,796 & 0.2384 & 0 & 0.4261 \\
\hline Propose remote animations/activities (quizzes, network games, exchanges on a subject...) & Remote activities & 18,470 & 0.3816 & 0 & 0.4858 \\
\hline \multicolumn{6}{|l|}{$\begin{array}{l}\text { In the current context of lockdown and in a progressive way, do you think that your NPO } \\
\text { and its volunteers could mobilize in a civic approach, beyond its members and/or } \\
\text { beneficiaries? (multiple choices - for each answer, } 1 \text { : yes and } 0: \text { no) }\end{array}$} \\
\hline Yes, if the health authorities tell us how to do it & Ready to mobilize/health authorities & 20,419 & 0.2447 & 0 & 0.4299 \\
\hline Yes, subject to good protection of the volunteers themselves & Ready to mobilize/protection of volunteers & 20,419 & 0.3684 & 0 & 0.4824 \\
\hline No, because they are particularly mobilized for members and/or beneficiaries & Already mobilized & 20,419 & 0.1424 & 0 & 0.3495 \\
\hline No, because that's not the role of the NPO & No mobilization & 20,419 & 0.3976 & 0 & 0.4894 \\
\hline
\end{tabular}


Plaisance (2021)

Table 1 (continued)

\begin{tabular}{|c|c|c|c|c|c|}
\hline Questions and proposed answers & Modality name & $N$ & Mean & Median & $S D$ \\
\hline \multicolumn{6}{|l|}{ Dependent variables (in order to test Hypothesis 2 and Hypothesis 3 ) } \\
\hline \multirow{5}{*}{$\begin{array}{l}\text { To go further, what proportion of this activity are you able to maintain for the moment? } \\
\text { (one choice) }\end{array}$} & 5 - Maintaining $<20 \%$ & \multirow{5}{*}{19,901} & \multirow{5}{*}{4.4371} & \multirow{5}{*}{5} & \multirow{5}{*}{1.1198} \\
\hline & 4 - Maintaining $20-40 \%$ & & & & \\
\hline & 3 - Maintaining $40-60 \%$ & & & & \\
\hline & 2 - Maintaining $60-80 \%$ & & & & \\
\hline & 1 - Maintaining $>80 \%$ & & & & \\
\hline \multirow{4}{*}{$\begin{array}{l}\text { How many months of operations are covered by your cash flow, starting today? } \\
\text { (one choice) }\end{array}$} & 3 - Cash for more than 6 months & \multirow{4}{*}{16,042} & \multirow{4}{*}{1.8923} & \multirow{4}{*}{2} & \multirow{4}{*}{0.9431} \\
\hline & 2 - Cash for 3-6 months & & & & \\
\hline & 1 - Cash for less than 3 months & & & & \\
\hline & 0 - No cash flow & & & & \\
\hline
\end{tabular}

Note: For binary variables, the average is also the percentage of people who answered "yes" and the median is also the mode. For the two ordinal variables, the percentage of respondents that gave each answer are presented in Tables 2 and 3 , and the mode will be the major percentage.

The questions posed to the GVOs covered many dimensions. Two of them have been retained to provide an overall context: the direct effect of the crisis and administrative measures on the daily functioning of the organization and the economic impact of the situation. The evolution of the GVOs' social role is also studied in order to test Hypothesis 1.

In addition to these univariate analyses, bivariate analyses are proposed regarding the maintenance of operations and available cash because they are the only two ordinal variables. They are both studied according to the GVO's activity sector, its financial resources (as in its annual incomes), and the number of employees, in order to test the Hypothesis 2 and Hypothesis 3. Eleven sectors were provided:

1. Charity (e.g., charitable and humanitarian action in favour of all people in difficulty)

2. Social action (e.g., medico-social institutions, home assistance, support for the elderly)
3. Health (e.g., health centers, blood donation, prevention)

4. Advocacy (e.g., fight against discrimination, religious activities, animal protection)

5. Leisure (e.g., socio-cultural activities, social tourism, youth movements)

6. Education (e.g., training and insertion in the labour market)

7. Sports (e.g., clubs or not)

8. Culture (e.g., artistic organizations)

9. Economy (e.g., groups of professionals, consumer protection, economic development)

10. Local (e.g., organizations that support local communities)

11. Environment (e.g., the protection of the quality of life and the environment) 


\section{Plaisance (2021)}

\section{RESULTS}

The activity is considerably affected and relies on a new organization of the employees' work

Ninety percent of French GVOs suffered the consequences of the crisis and the lockdown. No sector was unaffected, and only a handful of organizations managed to be resilient. Seventy-five percent of the GVOs were able to maintain less than 20 percent of their activity. Ninety-three percent of organizations had to cancel their events during the lockdown. This result can be analyzed in two ways. On the one hand, GVOs in the charitable sector were the most resilient and cancelled fewer events than other sectors. On the other hand, the maintenance of seven percent of events is surprising in view of the extreme lockdown measures. Some of the events were remote and helped to reinforce the digitalization of GVOs.

GVOs with employees had to adapt their working conditions. The choice of a partial unemployment scheme was retained by the majority, as the state had set up a lump-sum allowance system. Public authorities took charge of up to 84 percent of the net wage. The rest of the wage remained the responsibility of the organization. Telework was retained by 33 percent of the organizations. Another system was used for employees with children: 14 percent of the organizations were able to utilize the childcare vacation compensated by the state. Finally, some organizations were able to partially maintain faceto-face work. The GVOs in the social action (32\% of them) and charity $(17 \%$ of them) sectors were above all able to maintain links with their beneficiaries.

\section{Social interactions are maintained if possible}

Beyond their work with beneficiaries, GVOs play a special role with their members and volunteers. The maintenance of solidarity links with volunteers during social distancing was the priority of 60 percent of the GVOs. Fifty percent of the organizations maintained these links to ensure the continuation of activities. Thirty-six percent only maintained information and accountability. Meanwhile, 17 percent of the organizations lost contact with their volunteers.

Maintaining links with the volunteers impacts the activities and mission of an organization. The vast majority of GVOs asked their volunteers to focus on their members and beneficiaries to keep in touch and to relay health information from the authorities.

Solidarity actions were also set up, but only in a minority of GVOs. Daily services such as shopping or childcare were offered by one GVO in seven. Assistance with administrative procedures was more widespread: one GVO out of four. Finally, 38 percent of the GVOs animated their community remotely. While the volunteers were confined, 15 percent of the GVOs were nevertheless able to mobilize them to help their members and beneficiaries.

Finally, the external social role of French GVOs is crucial for these organizations. Thus, 37 percent of GVOs were ready to engage their volunteers with citizens and public services if they were well protected. Twenty-five percent of the GVOs were waiting for instructions from the health authorities. Only 40 percent believed that strict lockdown should be respected.

\section{A strong economic impact on GVOs}

First of all, the GVOs in the sample are mainly financed through public funds and the financial participation of beneficiaries and/or members in the organization. Only 26 percent of them receive individual donations; 25 percent receive private funding, notably through sponsorship. The source of the organizations' income is indeed a determining factor in understanding their capacity to react to the crisis (e.g., see Lasby, 2021, for the Canadian case).

The crisis has had multiple economic effects. During the crisis in March 2020, GVOs were anticipating serious difficulties. Thirty-eight percent expected a significant loss of revenue. Consequently, 32 percent of the GVOs were concerned about the difficulties of free cash flow. The cancellation of activities or events also played a role in the loss of deferred financing 
(for $29 \%$ of the GVOs). The loss of public and private aid was also a serious risk. Advanced charges for cancelled activities weighed on budgets too. Finally, 16 percent feared a total loss of income.

The cash position of the French GVOs was considerably affected, since eight percent of them did not have any to begin with. Twenty-seven percent would not have enough to finance their operations beyond three months. Thirty-three percent were in an average situation while 32 percent had more than six months of cash.

\section{An analysis based on resources and sector}

Before presenting the results of the bivariate studies, it should be noted that 23 percent of French GVOs were already experiencing cash-flow difficulties before the crisis. The bivariate analyses carried out provide an understanding of the importance of the sector and of human and financial resources on the GVOs' viability, studied from the perspective of maintaining activity and having the cash flow available to cope with the activity reduction. The relevance of the results was verified using the chi-square test $\left(\mathrm{X}^{2}\right)$ and the coefficient of association between the variables was measured using Pearson's phi. These two indicators are included at the bottom of each results table.

The sectors that have been able to maintain their activity at the highest level are the GVOs related to health, social services, and local solidarity (see Table 2a). Conversely, the most affected sectors are those that cannot be dematerialized, such as sports, some cultural activities, and leisure. Regardless of the sector, having few or no employees has limited the ability of GVOs to maintain their activity (see Table $2 b$ ). Eighty-four percent of GVOs with only volunteers were operating at less than 20 percent of their usual activity. As the number of employees increased, the easier it was for an organization to maintain activity. However, half of the structures employing more than 50 people almost stopped their activities. The argument is the same for the available budget (see Table 2c). Three out of four organizations with incomes of less than 100,000€ per year lost more than 80 percent of their activity. Even a budget of more than 500,000€ was only partially protective, since one out of two of those organizations saw more than 80 percent of its activities interrupted.

Table 2a: Analysis of activity maintenance according to the sector

\begin{tabular}{|c|c|c|c|c|c|c|c|c|c|c|c|c|}
\hline & Charity & $\begin{array}{c}\text { Social } \\
\text { action }\end{array}$ & Health & Advocacy & Leisure & Education & Sport & Culture & Economy & Local & Environment & All \\
\hline$>80 \%$ & $10 \%$ & $7 \%$ & $10 \%$ & $7 \%$ & $4 \%$ & $6 \%$ & $3 \%$ & $4 \%$ & $15 \%$ & $10 \%$ & $9 \%$ & $5 \%$ \\
\hline $60-80 \%$ & $10 \%$ & $9 \%$ & $8 \%$ & $11 \%$ & $3 \%$ & $9 \%$ & $1 \%$ & $4 \%$ & $4 \%$ & $9 \%$ & $10 \%$ & $4 \%$ \\
\hline $40-60 \%$ & $16 \%$ & $16 \%$ & $12 \%$ & $14 \%$ & $5 \%$ & $12 \%$ & $2 \%$ & $7 \%$ & $15 \%$ & $15 \%$ & $12 \%$ & $7 \%$ \\
\hline $20-40 \%$ & $17 \%$ & $15 \%$ & $17 \%$ & $17 \%$ & $8 \%$ & $16 \%$ & $3 \%$ & $9 \%$ & $22 \%$ & $18 \%$ & $15 \%$ & $9 \%$ \\
\hline$<20 \%$ & $47 \%$ & $53 \%$ & $52 \%$ & $51 \%$ & $81 \%$ & $58 \%$ & $91 \%$ & $76 \%$ & $45 \%$ & $48 \%$ & $54 \%$ & $75 \%$ \\
\hline$N$ & 779 & 1,501 & 350 & 298 & 2,933 & 1,128 & 7,305 & 3,144 & 115 & 699 & 668 & \\
\hline
\end{tabular}

Note: $X^{2}=115.6^{* \star *}(p<0.001)$; Pearson's phi $=0.32$ 
Plaisance (2021)

Table $2 \mathrm{~b}$ : Analysis of activity maintenance according to the number of employees

\begin{tabular}{|c|c|c|c|c|c|c|c|c|}
\hline & $\mathbf{0}$ & $\mathbf{1}$ or $\mathbf{2}$ & $\mathbf{3}$ to $\mathbf{5}$ & $\mathbf{6}$ to $\mathbf{9}$ & $\mathbf{1 0}$ to $\mathbf{1 9}$ & $\mathbf{2 0}$ to $\mathbf{4 9}$ & $>\mathbf{5 0}$ & All \\
\hline$>80 \%$ & $5 \%$ & $4 \%$ & $6 \%$ & $5 \%$ & $6 \%$ & $7 \%$ & $9 \%$ & $5 \%$ \\
\hline $60-80 \%$ & $2 \%$ & $4 \%$ & $5 \%$ & $7 \%$ & $8 \%$ & $7 \%$ & $11 \%$ & $4 \%$ \\
\hline $40-60 \%$ & $4 \%$ & $7 \%$ & $10 \%$ & $11 \%$ & $11 \%$ & $11 \%$ & $17 \%$ & $7 \%$ \\
\hline $20-40 \%$ & $5 \%$ & $9 \%$ & $11 \%$ & $12 \%$ & $13 \%$ & $14 \%$ & $14 \%$ & $9 \%$ \\
\hline$<20 \%$ & $84 \%$ & $77 \%$ & $68 \%$ & $64 \%$ & $62 \%$ & $60 \%$ & $49 \%$ & $75 \%$ \\
\hline$N$ & 7,743 & 4,923 & 2,589 & 1,486 & 1,463 & 953 & 572 & \\
\hline
\end{tabular}

Note: $X^{2}=38.1^{*}(p<0.05) ;$ Pearson's phi $=0.23$

Table 2c: Analysis of activity maintenance according to the annual incomes

\begin{tabular}{|c|c|c|c|c|c|c|c|}
\hline & $<10 \mathrm{k} €$ & $10-50 \mathrm{k} €$ & $50-100 \mathrm{k} €$ & $100-200 \mathrm{k} €$ & 200-500k€ & $>500 \mathrm{k} €$ & All \\
\hline$>80 \%$ & $5 \%$ & $4 \%$ & $4 \%$ & $5 \%$ & $6 \%$ & $8 \%$ & $5 \%$ \\
\hline $60-80 \%$ & $2 \%$ & $3 \%$ & $4 \%$ & $5 \%$ & $7 \%$ & $10 \%$ & $4 \%$ \\
\hline $40-60 \%$ & $4 \%$ & $4 \%$ & $6 \%$ & $10 \%$ & $12 \%$ & $14 \%$ & $7 \%$ \\
\hline $20-40 \%$ & $5 \%$ & $7 \%$ & $10 \%$ & $11 \%$ & $13 \%$ & $15 \%$ & $9 \%$ \\
\hline$<20 \%$ & $85 \%$ & $82 \%$ & $76 \%$ & $69 \%$ & $63 \%$ & $53 \%$ & $75 \%$ \\
\hline$N$ & 5,102 & 5,020 & 2,580 & 2,227 & 2,056 & 2,360 & \\
\hline
\end{tabular}

Note: $X^{2}=38.8^{* *}(p<0.01) ;$ Pearson's phi $=0.25$

The financial difficulties encountered by GVOs vary by sector (see Tables 3a, 3b, and 3c). The sectors that mobilize the most in times of a health crisis faced the greatest challenges. However, intra-sectoral diversities should be noted. Even though 12 percent of the health GVOs had no cash, 43 percent of them had more than six months of cash. The same diversity can be found in terms of employees. GVOs with liquidity problems were more numerous among those without employees. But 50 percent of them also had more than six months of cash. As the number of employees increased, the liquidity risks decreased but so did the six-month cash reserves (due, in particular, to the salaries to be paid). Finally, the annual incomes also show that the smallest GVOs are those with the least cash-flow problems (especially because the "no cash flow" modality is around five to ten percent of the organizations). 
Plaisance (2021)

Table 3a: Analysis of cash flow according to the sector

\begin{tabular}{|c|c|c|c|c|c|c|c|c|c|c|c|c|}
\hline & Charity & $\begin{array}{c}\text { Social } \\
\text { action }\end{array}$ & Health & Advocacy & Leisure & Education & Sport & Culture & Economy & Local & Environment & All \\
\hline No cash flow & $10 \%$ & $10 \%$ & $12 \%$ & $9 \%$ & $7 \%$ & $9 \%$ & $6 \%$ & $8 \%$ & $8 \%$ & $7 \%$ & $9 \%$ & $8 \%$ \\
\hline$<3$ months & $22 \%$ & $37 \%$ & $18 \%$ & $27 \%$ & $29 \%$ & $37 \%$ & $21 \%$ & $27 \%$ & $30 \%$ & $31 \%$ & $38 \%$ & $27 \%$ \\
\hline 3 - 6 months & $33 \%$ & $34 \%$ & $27 \%$ & $24 \%$ & $34 \%$ & $34 \%$ & $35 \%$ & $33 \%$ & $23 \%$ & $36 \%$ & $32 \%$ & $33 \%$ \\
\hline$>6$ months & $36 \%$ & $19 \%$ & $43 \%$ & $40 \%$ & $29 \%$ & $20 \%$ & $38 \%$ & $32 \%$ & $40 \%$ & $26 \%$ & $21 \%$ & $32 \%$ \\
\hline$N$ & 779 & 1,501 & 350 & 298 & 2,933 & 1,128 & 7,305 & 3,144 & 115 & 699 & 668 & \\
\hline
\end{tabular}

Note: $X^{2}=49.6^{*}(p<0.05) ;$ Pearson's phi $=0.21$

Table 3b: Analysis of cash flow according to the number of employees

\begin{tabular}{|c|c|c|c|c|c|c|c|c|}
\hline & $\mathbf{0}$ & $\mathbf{1}$ or $\mathbf{2}$ & $\mathbf{3}$ to $\mathbf{5}$ & $\mathbf{6}$ to $\mathbf{9}$ & $\mathbf{1 0}$ to $\mathbf{1 9}$ & $\mathbf{2 0}$ to $\mathbf{4 9}$ & $\mathbf{>} \mathbf{5 0}$ & All \\
\hline No cash flow & $11 \%$ & $6 \%$ & $7 \%$ & $5 \%$ & $6 \%$ & $6 \%$ & $5 \%$ & $8 \%$ \\
\hline$<3$ months & $15 \%$ & $27 \%$ & $33 \%$ & $35 \%$ & $41 \%$ & $45 \%$ & $46 \%$ & $27 \%$ \\
\hline $3-6$ months & $24 \%$ & $37 \%$ & $41 \%$ & $42 \%$ & $40 \%$ & $40 \%$ & $36 \%$ & $33 \%$ \\
\hline$>6$ months & $50 \%$ & $29 \%$ & $0 \%$ & $18 \%$ & $12 \%$ & $9 \%$ & $13 \%$ & $32 \%$ \\
\hline$N$ & 7,743 & 4,923 & 2,589 & 1,486 & 1,463 & 953 & 572 & \\
\hline
\end{tabular}

Note: $X^{2}=86.1^{* * *}(p<0.001) ;$ Pearson's phi $=0.35$

Table 3c: Analysis of cash flow according to the annual incomes

\begin{tabular}{|c|c|c|c|c|c|c|c|}
\hline & $<10 \mathbf{\epsilon}$ & $\mathbf{1 0 - 5 0 k} €$ & $\mathbf{5 0 - 1 0 0 k €}$ & $\mathbf{1 0 0 - 2 0 0 k} €$ & $\mathbf{2 0 0 - 5 0 0 k €}$ & $>\mathbf{5 0 0 k} €$ & All \\
\hline No cash flow & $10 \%$ & $7 \%$ & $8 \%$ & $7 \%$ & $7 \%$ & $5 \%$ & $8 \%$ \\
\hline$<3$ months & $13 \%$ & $22 \%$ & $28 \%$ & $33 \%$ & $40 \%$ & $41 \%$ & $27 \%$ \\
\hline $3-6$ months & $23 \%$ & $32 \%$ & $39 \%$ & $39 \%$ & $40 \%$ & $40 \%$ & $33 \%$ \\
\hline$>6$ months & $54 \%$ & $39 \%$ & $25 \%$ & $22 \%$ & $13 \%$ & $14 \%$ & $32 \%$ \\
\hline$N$ & 5,102 & 5,020 & 2,580 & 2,227 & 2,056 & 2,360 & \\
\hline
\end{tabular}

Note: $X^{2}=73^{* * *}(p<0.001) ;$ Pearson's phi $=0.35$ 


\section{Plaisance (2021)}

\section{DISCUSSION AND CONCLUSION}

\section{Hypotheses statement and their contextualization}

The GVOs' socio-political role remains primordial. Despite all the difficulties encountered-problems of activity continuity, difficulty maintaining links with certain volunteers, and fears about the financial and economic viability-French GVOs have tried to maintain their social and political role. To this end, they made efforts to communicate, even remotely, with their volunteers, members, and beneficiaries. They have also offered services, sometimes unrelated to their activity. Finally, they have expressed their desire to support the public authorities, particularly through communication.

The obtained results (Table 1) illustrate that, by offering services to the community around them, French GVOs are indeed public goods providers and have proven to be reliable (Hansmann, 1986). Moreover, the French GVOs' volunteers have taken on health risks. They have made sacrifices to help other volunteers, members, or beneficiaries, as pointed out by Tocqueville. Finally, they have maintained a managerial dialogue through governance and accountability, but also more informal exchanges to ensure that the social link is not cut. Relaying health information was also one of their concerns. The GVOs' discourse on solidarity and well-being was not inconsequential. In short, Hypothesis 1 is supported.

The results can also be discussed according to the different mobilized resources. The concept of organizational capacity is a relevant filter, as previously explained, and is based on financial, human resources, and structural capacities. The next paragraphs focus on these three dimensions.

The financial capital of the GVOs was not spared by the crisis, but the most serious problems only concerned a minority of structures. The results point to a strong dependency of these GVOs on their funders. The partial or total loss of income linked to the cessation of activity and the loss of subsidies linked to a project illustrates the changeover already noticed by Viviane Tchernonog (2007): the financing of GVOs is based on their projects and not on their mission. Dependency on private funders also confirms the observation of Tchernonog and Lionel Prouteau (2019): the financing of GVOs is now mostly private. Table 2b confirms Rui Sun and Hugo Asencio's (2019) analysis of the positive role of organizational capacity, examined here from the perspective of financial capacity, in effectiveness. Finally, the results in Table 3a illustrate the theoretical framework proposed by Hall et al. (2003). The sector environment largely explains the available cash flow. However, while this same theoretical framework emphasizes the importance of human capital in understanding financial capacity, the results are more contrasted in terms of the relationship between the number of employees and cash flow (Table 3b).

Human resources capacity is the second dimension. The new working and commitment modalities as well as the mobilization of volunteers described in Table 1 underline the extent to which the French "associations" are indeed GVOs. Human capital is a condition for survival, and having employees protected the maintenance of an organization's activity, according to Table 2b. In short, Hypothesis 2 is supported and Hypothesis 3 has to be contrasted with financial capacity.

The concept of organizational capacity can thus be discussed by the results obtained. It captures all the available resources that an organization can mobilize in order to function, develop its projects, and achieve its objectives (Eisinger, 2002; Shumate, Cooper, Pilny, \& Pena-y-lillo, 2017). In the case of GVOs, individuals create many synergies within the organization (Schuh \& Leviton, 2006). However, the results contrast with the idea that the majority of resources are immaterial, since in French GVOs people are the most important. Moreover, the process described by the theoretical framework of Hall et al. (2003) is only partially found here, since human resource capacity has a complex effect on financial capacity.

Moreover, here, structural capacity has to be focused in particular on relationship and network capacity, understood as "the ability to draw on relationships with clients, members, funders, partners, government, the media, corporations, vol- 


\section{Plaisance (2021)}

unteers, and the public" (Hall et al., 2003, p. 5). The importance of this relationship was seen above in terms of dependency on funders and on employees and volunteers. Beyond that, maintaining links between the organization and its volunteers and between its members and beneficiaries was at the heart of the GVO's functioning during the crisis. This is the social and civic role of the GVOs, analyzed above.

\section{Research questions statement and contributions}

The research questions asked about the links between crisis and resources: how a crisis affects resources (RQ1) and the extent to which resources can protect against the impact of the crisis (RQ2). Regarding RQ1, the various results show that all the resources of French GVOs were damaged during the COVID-19 crisis, in particular because restrictions prevented volunteers from being present on site and prohibited most of the usual activities and events. In addition, financial stakes multiplied in the short and medium terms. This observation must be tempered, however, with the fact that the GVOs' human capital enabled them to maintain their social and civic role. It is a first answer to RQ2. Whenever possible, GVOs tried to convert the social capital they usually create into a daily social and human connection. Finally, in order to fully answer RQ2 on one hand, pre-crisis resources protected GVOs from a sudden stoppage of activity. On the other hand, financial issues, particularly liquidity risk, were more complex.

This work calls on several contributions. First, it applies the resource dependency theory and the concept of organizational capacity to French GVOs. According to Deana Raffo, Leigh Anne Clark, and Murat Arik (2016), this approach has been little applied to NPOs. By extension, the use of this theory in the case of French GVOs is still rare. This theory proved to be relevant in this context: the lack of resources quickly turned out to be deleterious for GVOs. The concept of organizational capacity was a relevant filter for analyzing GVOs' resources, and Hall et al.'s (2003) model was discussed. In addition, the results illustrated how theories dedicated to NPOs in general can be applied to French cases, as seen with the hypotheses development. Finally, the study covers a wide range of organizations, from all sectors and of all sizes (in terms of funding and employees).

Second, practitioner contributions primarily concern NPOs' stakeholders. The resources they bring are crucial to their survival. In times of crisis, NPOs have played a fundamental social role for their communities. However, this role is intangible and almost impossible to measure. This is why the increase in requirements in terms of evaluation and financial performance is a real threat to NPOs and their sustainability. These expectations must be accompanied by the associated means, otherwise NPOs will end up in a vicious circle that forces them to finance new management activities in order to obtain funding. The authorities must remember the political and civic role of GVOs and continue to involve them in their policies. Democratically shared power will prevent the curse of the Medici, who had concentrated politics and economics in their hands (Zingales, 2017). In addition, the survey results and analysis provide a picture of the GVOs' dependencies on their resource providers and test the resilience of the sector. It is a source of information for GVOs. Resources are a major issue that generally explain the management weaknesses of GVOs, as discussed above. Thus, the findings encourage stakeholders to ensure that their expectations can be met in a context of strained resources.

\section{CONCLUSION}

Based on a broad survey of French GVOs during the first lockdown in March 2020, four types of analyses were carried out, focusing on the maintenance of activity, the persistence of the social and civic role of the GVOs, the financial health of GVOs, and the importance of human and financial resources. This article completes the publication of the results by the involved actors (Le Mouvement associatif, RNMA, public authorities, and Recherches \& Solidarités) by integrating it into a specific theoretical framework. This article is among the first to look at the consequences of the COVID-19 crisis on French NPOs. 


\section{Plaisance (2021)}

There are some limitations to this study. It is based on a database; therefore, the questions and proposed answers are neither adjustable nor controlled. Most of the variables are either binary or ordinal. Complementary analyses based on metrics and interviews could be carried out in order to grasp the contours of the social and civic role of NPOs that are not perceived in the questionnaire.

\section{ACKNOWLEDGEMENTS}

The author wishes to thank Jacques Malet, Cécile Bazin, and Marie Duros of Recherches \& Solidarités for their kind provision of the COVID-19 survey database and their support in the research process undertaken on the basis of this survey.

\section{WEBSITES}

République Française, https://www.legifrance.gouv.fr/loda/id/JORFTEXT000029313296/

Le Mouvement Associatif, https://lemouvementassociatif.org/

Recherches \& Solidarités, https://recherches-solidarites.org/

Réseau National des Maisons des Associations, https://www.maisonsdesassociations.fr/

\section{REFERENCES}

Baapogmah, F.A., Mayer, R.W., Chien, W.-W., \& Afolabi, A. (2015). Control mechanisms and accountability challenges in nonprofit organizations. Global Journal of Business Research, 9(1), 27-38.

Barr, C. (2020). A post Covid-19 agenda for nonprofit \& social economy research. Canadian Journal of Nonprofit and Social Economy Research, 11(1), 1-4. doi:10.29173/cjnser.2020v11n1a373

Behn, B.K., DeVries, D.D., \& Lin, J. (2010). The determinants of transparency in nonprofit organizations : An exploratory study. Advances in Accounting, 26(1), 6-12. doi:10.1016/j.adiac.2009.12.001

Burger, R., \& Owens, T. (2010). Promoting transparency in the NGO sector: Examining the availability and reliability of self-reported data. World Development, 38(9), 1263-1277. doi:10.1016/j.worlddev.2009.12.018

Cabedo, J.D., Fuertes-Fuertes, I., Maset-LLaudes, A., \& Tirado-Beltrán, J.M. (2018). Improving and measuring transparency in NGOs : A disclosure index for activities and projects. Nonprofit Management and Leadership, 28(3), 329-348. doi:10.1002/nml.21298

Chokkalingam, T.S.V., \& Ramachandran, T. (2015). The perception of donors on existing regulations and code of governance in Singapore on charities and non-profit organizations - A conceptual study. Asian Social Science, 11(9), 89-95.

Dadić, L., \& Ribarić, H.M. (2020). Improving the financial sustainability of nonprofit organizations through tourism-related activities. International Journal of Nonprofit and Voluntary Sector Marketing. doi:10.1002/nvsm.1692

Dubost, N., \& Zoukoua, E.-A. (2011). Qu'est-ce qu'une association performante ? Apport et influence des représentations sociales dans le secteur social et médico-social. Comptabilités, économie et société, 1(10), 1-23.

Eisinger, P. (2002). Organizational capacity and organizational effectiveness among street-level food assistance programs. Nonprofit and Voluntary Sector Quarterly, 31(1), 115-130.

Evers, A., \& Laville, J.-L. (2004). The third sector in Europe. Cheltenham, UK: Edward Elgar Publishing.

Ferraton, C. (2004). L'idée d'association chez Alexis de Tocqueville. Cahiers d Économie Politique, 46(1), 45-65. doi:10.3917/cep.046.0045

Greiling, D., Harris, M., \& Stanley, R. (2016). Accountability in non-profit organizations introduction to the symposium. Public Administration Quarterly, 40(2), 212-219.

Hall, M.H. (2004). Cornerstones of community: Highlights of the national survey of nonprofit and voluntary organizations. Ottawa, ON: Statistics Canada, Business and Trade Statistics Field. 


\section{Plaisance (2021)}

Hall, M.H., Andrukow, A., Barr, C., Brock, K., de Wit, M., \& Embuldeniya, D. (2003). The Capacity to serve: A qualitative study of the challenges facing Canada's nonprofit and voluntary organizations. Toronto, ON: Canadian Centre for Philanthropy.

Hamidi, C. (2010). La société civile dans les cités : Engagement associatif et politisation dans des associations de quartier. Paris, Economica.

Hansmann, H. (1986). The role of nonprofit enterprise. In S. Rose-Ackerman (Ed.), The economics of nonprofit institutions: Studies in structure and policy (pp. 57-84). Oxford, UK: Oxford University Press.

Kelly, D., \& Lewis, A. (2009). Human service sector nonprofit organization's social impact. Business Strategy Series, 10(6), 374-382. doi:10.1108/17515630911005664

Kim, M., \& Mason, D.P. (2020). Are you ready: Financial management, operating reserves, and the immediate impact of COVID-19 on nonprofits. Nonprofit and Voluntary Sector Quarterly, 49(6), 1191-1209. doi:10.1177/08997640 20964584

Lasby, D. (2021). Imagine Canada's sector monitor: Ongoing effects of the COVID-19 pandemic. Toronto, ON: Imagine Canada.

Laville, J.-L. (2002). L'association comme lien social. Connexions, 77(1), 43-54. doi:10.3917/cnx.077.0043

Loomis, J. (2020). The COVID wildfire: Non-profit organizational challenge and opportunity. Canadian Journal of Nonprofit and Social Economy Research, 11(2), 8-11. doi:10.29173/cjnser.2020v11n2a396

Mano, R. (2010). Organizational crisis, adaptation, and innovation in Israel's nonprofit organizations: A learning approach. Administration in Social Work, 34(4), 344-350. doi:10.1080/03643107.2010.500985

Mano, R., \& Rosenberg, D. (2014). Organizational restructuring, government control and loss of legitimacy following an organizational crisis: The case of Israel's nonprofit human services. Journal of Health and Human Services Administration, 36(4), 460-497. JSTOR.

McMullin, C., \& Raggo, P. (2020). Leadership and governance in times of crisis: A balancing act for nonprofit boards. Nonprofit and Voluntary Sector Quarterly, 49(6), 1182-1190. doi:10.1177/0899764020964582

Ministère de l'économie, des finances et de la relance. (2014). Tout savoir et tout comprendre sur la loi Economie sociale et solidaire-ESS : trois lettres pour une nouvelle économie. Paris, Secrétariat d'État chargée du Commerce, de l'Artisanat, de la Consommation et de l'Économie Sociale et Solidaire. URL: https://www.economie .gouv.fr/files/files/PDF/ess-brochure.pdf [accessed on June 13, 2021].

Misener, K., Morrison, K., Shier, M., \& Babiak, K. (2020). The influence of organizational social responsibility on involvement behavior in community sport membership associations. Nonprofit Management and Leadership, 30(4), 591-611. doi:10.1002/nml.21406

Mitchell, G.E., \& Berlan, D. (2016). Evaluation and Evaluative Rigor in the Nonprofit Sector. Nonprofit Management and Leadership, 27(2), 237-250. doi:10.1002/nml.21236

Mourão, P., Pereira, T., \& Moreira, M.C. (2017). The importance of new forms of capital in nonprofit organizations: A case study of the Fafe delegation of the Portuguese Red Cross. International Journal of Social Economics, 44(7), 846-868.

O'Dwyer, B., \& Unerman, J. (2008). The paradox of greater NGO accountability: A case study of Amnesty Ireland. Accounting, Organizations and Society, 33(7), 801-824. doi:10.1016/j.aos.2008.02.002

Omura, T., \& Forster, J. (2014). Competition for donations and the sustainability of not-for-profit organisations. Humanomics, 30(3), 255-274. doi:10.1108/H-12-2012-0026

Pearson, C.M., \& Clair, J.A. (1998). Reframing crisis management. Academy of Management Review, 23(1), 59-76. doi:10.5465/amr.1998.192960

Pfeffer, J., \& Salancik, G.R. (1978). The external control of organizations: A resource dependence perspective. New York, NY: Harper \& Row.

Plaisance, G. (2017). L'engagement: Ni militant, ni syndical, ni partisan - Les nouvelles formes de volontariat. Limoges, FYP éditions. 


\section{Plaisance (2021)}

Pozil, S., \& Hacker, A. (2017). Informal partnerships between nonprofits and local governments and the role of trust. Journal of Social Change, 9(1), 67-76. doi:10.5590/JOSC.2017.09.1.06

Raffo, D.M., Clark, L.A., \& Arik, M. (2016). Strategic responses of non-profit organizations to the economic crisis : Examining through the lenses of resource dependency and resourced-based view theories. Academy of Strategic Management Journal, 15(1), 48-70.

République Française. (2014, July 14). Article 1 of the "Loi n² 2014-856 du 31 juillet 2014 relative à l'économie sociale et solidaire." URL: https://www.legifrance.gouv.fr/loda/id/JORFTEXT000029313296/ [June 13, 2021].

Rey García, M., Álvarez González, L.I., \& Bello Acebrón, L. (2013). The untapped potential of marketing for evaluating the effectiveness of nonprofit organizations: A framework proposal. International Review on Public and Nonprofit Marketing, 10(2), 87-102. doi:10.1007/s12208-012-0085-1

Sargeant, A. (2001). Relationship fundraising: How to keep donors loyal. Nonprofit Management and Leadership, 12(2), 177-192. doi:10.1002/nml.12204

Schuh, R.G., \& Leviton, L.C. (2006). A framework to assess the development and capacity of non-profit agencies. Evaluation and Program Planning, 29(2), 171-179. doi:10.1016/j.evalprogplan.2005.12.001

Shumate, M., Cooper, K.R., Pilny, A., \& Pena-y-lillo, M. (2017). The nonprofit capacities instrument: The nonprofit capacities instrument. Nonprofit Management and Leadership, 28(2), 155-174. doi:10.1002/nml.21276

Sobeck, J., \& Agius, E. (2007). Organizational capacity building: Addressing a research and practice gap. Evaluation and Program Planning, 30(3), 237-246. doi:10.1016/j.evalprogplan.2007.04.003

Stokkink, D., \& Perard, P. (2015). L'économie sociale et solidaire en Europe. In R. Holcman (Ed.), Économie sociale et solidaire. Malakoff, Dunod.

Sun, R., \& Asencio, H.D. (2019). Using social media to increase nonprofit organizational capacity. International Journal of Public Administration, 42(5), 392-404. doi:10.1080/01900692.2018.1465955

Tchernonog, V. (2007). Le paysage associatif français et ses évolutions - Profil, financement, dirigeants, emploi salarié, travail bénévole. Paris, Dalloz.

Tchernonog, V., \& Prouteau, L. (2019). Le paysage associatif français: Mesures et évolutions. Paris, Dalloz.

Tschirhart, M., \& Gazley, B. (2014). Advancing scholarship on membership associations: New research and next steps. Nonprofit and Voluntary Sector Quarterly, 43(2_suppl), 3S-17S. doi:10.1177/0899764013517052

Weerawardena, J., McDonald, R.E., \& Mort, G.S. (2010). Sustainability of nonprofit organizations: An empirical investigation. Journal of World Business, 45(4), 346-356. doi:10.1016/j.jwb.2009.08.004

Weisbrod, B.A. (1988). The nonprofit economy. Cambridge, MA: Harvard University Press.

Zingales, L. (2017). Towards a political theory of the firm. Journal of Economic Perspectives, 31(3), 113-130. doi:10.1257/jep.31.3.113

\section{ABOUT THE AUTHOR / L'AUTEUR}

Guillaume Plaisance is PhD candidate and lecturer at the University of Bordeaux. Email: guillaume.plaisance @u-bordeaux.fr 